\title{
Nitrogen Biofertilizer Alleviates the Inhibitory Effect of Cadmium on Physiology and Nitrogen Assimilation in Maize Plants
}

\author{
Hanan Mahmoud Abou-Zeid ${ }^{1}$, Nabil El-Sayed Saber ${ }^{1}$, Basma Ibrahim Abdelrahim ${ }^{2}$ and Ghada Saber Mohamed \\ Ismail $^{1^{*}}$ \\ ${ }^{1}$ Botany and Microbiology Department, Faculty of Science, Alexandria University, Egypt \\ ${ }^{2}$ Botany Department, Faculty of Science, Benghazi University, Libia \\ *For correspondence: ghada5f@yahoo.com \\ Received 11 April 2020; Accepted 05 September 2020; Published 10 December 2020
}

\begin{abstract}
The present study investigated the role of inoculation with Nitrobien biofertilizer (N-Bio, Azospirillum and azotobacter spp.)

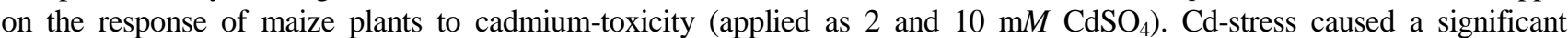
reduction in the fresh and dry biomass of leaves and roots as well as a marked disturbance in the anatomical features of roots and stomatal structure and behavior. Cd-stress significantly depressed the total photosynthetic pigments, photochemical efficiency of PS II, total carbohydrates, and proteins content. Furthermore, increasing Cd level prompted oxidative stress measured in terms of malondialdehyde and $\mathrm{H}_{2} \mathrm{O}_{2}$ contents in maize plants. Application of N-Bio improved these attributes in $\mathrm{Cd}$-stressed maize plants. Moreover, $\mathrm{NO}_{3}{ }^{-}$uptake and its assimilating enzymes (nitrate reductase, NR; glutamine synthase, $\mathrm{GS}$; and, glutamate dehydrogenase GDH) were significantly increased in N-Bio-pretreated Cd-stressed plants than Cdstressed ones and that was associated with a decrease of $\mathrm{NH}_{4}{ }^{+}$content. $\mathrm{N}$-Bio pretreatment also stimulated the accumulation of amino acids and markedly increased endogenous phytohormone content (IAA, $\mathrm{GA}_{3}$ ) of Cd-stressed maize plants. These results revealed the potentiating effect of $\mathrm{N}$-Bio pretreatment in regulating $\mathrm{Cd}$-induced damages in maize plants. (C) 2021 Friends Science Publishers
\end{abstract}

Keywords: Biofertilizer; Cadmium stress; Root anatomy; Phytohormone; Nitrate reductase

\section{Introduction}

Plants are exposed to several abiotic and biotic stresses. In the present era, heavy metals have been widely distributed; being one of the major outstanding apprehensions for sustainable agriculture and human welfare (Edelstein and Ben-Hur 2018). Cadmium (Cd) is a non-essential heavy metal that occurs naturally in the environment in traces; however, its concentration is continuously increased due to extensive industrial processes, dispersal of sewage sludge and usage of phosphate fertilizers in agriculture (Liu et al. 2007). Furthermore, Cd uptake alters plant growth and development, and affects human health by its accumulation in the consumable parts of crop plants.

The processes related to $\mathrm{Cd}$ toxicity in plants are very complicated as it can affect several morphological and physiological processes even at low concentrations. Excessive amounts of $\mathrm{Cd}$ frequently elicits many stress symptoms in plants, such as decrease of carbon assimilation, generation of oxidative stress, inhibition of chlorophyll synthesis, reduction in nutrient uptake, impairment of photosynthesis and at last bringing about stunted growth, chlorosis, leaf epinasty, alterations in chloroplast ultrastructure, induction of lipid peroxidation, alterations in nitrogen $(\mathrm{N})$ metabolism and interruption of antioxidant machinery (Shah et al. 2017; Farooq et al. 2020). It is well known that $\mathrm{Cd}$ is more easily absorbed by plants than any other heavy metals and more than $90 \%$ of the $\mathrm{Cd}$ is accumulated in roots (Hussain et al. 2021). Although most studies had focused on the impact of heavy metals on visible symptoms on aerial parts and root morphological characters, few studies had recorded toxic symptoms on the anatomical parameters of several plants grown under cadmium stress including maize (Gowayed and Almaghrabi 2013) and rice (Li et al. 2014). It is well known that stomata play an important role in adjustment of plant water balance and gas exchange. Alterations in stomatal structure and behavior have been observed due to different heavy metals toxicity as Cd (Mondal et al. 2013) and Pb (Divyajyothi and Sujatha 2019).

It has been shown that nitrate uptake and its assimilation by plants are differently affected under $\mathrm{Cd}$ treatment (Chaffei et al. 2004). Nikolić et al. (2017) reported that increasing $\mathrm{Cd}$ levels markedly decline $\mathrm{NO}_{3}{ }^{-}$uptake and 
its assimilation as indicated by suppressing nitrate reductase (NR) and glutamine synthetase (GS) activities. Singh and Prasad (2017) found a marked decline in glutamine synthetase-glutamate synthase (GS/GOGAT) activities in tomato plants imposed to $\mathrm{Cd}$ treatment. They suggested that the decline of both GS and GOGAT activities could result in the accumulation of $\mathrm{NH}_{4}{ }^{+}$and a decrease of growth. On the other hand, other researchers (Chaffei et al. 2004; Skopelitis et al. 2006) have recorded an increase of glutamate dehydrogenase (NADH-GDH) activity under Cd stress.

The plants exposed to toxic elements tend to accumulate specific amino acid (AAs), which may have valuable functions and play various roles in plants (Xu et al. 2012; Zemanová et al. 2017). It is well recognized that long-term application of chemical fertilizers contributes to the pollution of soil and ground water with various heavy metals, soil degradation and destruction of soil microflora (Rashid et al. 2016). On the other hand, biofertilizers are different types of living population microorganisms, such as bacteria, fungi and cyanobacteria, live in plants root vicinity or rhizosphere and have the ability to stimulate plant growth through different modes of actions such as nitrogen fixation, degradation of organic materials and secretion of phytohormones (Sinha et al. 2014).

Recent studies have also demonstrated that application of various strains of plant growth promoting rhizobacteria (PGPR) can promote and improve several plants subjected to various environmental stresses (Naveed et al. 2014; Gouda et al. 2018). Bacteria of the genus Azospirillum and Azotobacter are among the best researched PGPR detected in the rhizosphere of many crop plants like wheat and tomato (Agami et al. 2017; Reddy et al. 2018). They exert their roles through $\mathrm{N}_{2}$ fixation, secretion of several components as vitamins, plant growth regulators and several natural products as secondary metabolites in the rhizosphere (Vejan et al. 2016). Such capabilities accordingly result in enhanced growth of plants under various stresses like drought and heavy metal stress (Agami et al. 2017; Rezvi and Khan 2018). Previously, Pacwa-Płociniczak et al. (2011) stated that bacterial biosurfactants can bind toxic heavy metals, hence remove them from soil and increase plant tolerance.

Maize (Zea mays L.) is one of the most economically important cereal crops utilized for grain, silage, and biofuel goals (Tejada et al. 2016). An exponential increment in the world populace would request a higher crop production and hence more utilizations of chemical fertilizers. Therefore, the aim of the current investigation was to study the impact of Cd stress on Zea mays and evaluate the role of Nitrobien biofertilizer applied by seed inoculation in the response of maize plants to Cd stress. The modifications in some growth parameters, photosynthetic efficiency, stomatal behavior, and root anatomical structures were followed. In addition, nitrate, ammonia, free amino acids and hormonal content as well as nitrogen assimilating enzymes activity were evaluated.

\section{Materials and Methods}

\section{Plant material, growth conditions and treatments}

Maize (Zea mays L. cv. Nevertity) seeds were obtained from the Agricultural Research Center, Giza, Egypt. Nitrobien biofertilizer (N-Bio) containing a combination of nitrogen-fixing bacteria; Azotobacter spp. and Azospirillum spp. were kindly supplied by biofertilizers Unit, General Organization of Agriculture Equalization Fund, Agriculture Research Centre, Ministry of Agriculture, Giza, Egypt. After surface-sterilization with $4 \%$ sodium hypochlorite for $10 \mathrm{~min}$, the seeds were washed with distilled water several times, soaked for $24 \mathrm{~h}$ at $25^{\circ} \mathrm{C}$ in aerated water and then transferred to weighed plastic pots filled with acid-washed quartz sand and clay (3:1). The pots were divided into four groups and each group consists of 3 replicates. The first group was left as a control without any treatment and irrigated with one tenth strength modified Hoagland solution (Epstein 1972). The second group was irrigated with one tenth strength modified Hoagland solution supplemented with 2 and $10 \mathrm{mMCdSO}$. In the third group the soaked seeds were inoculated with $\mathrm{N}$-Bio; seed inoculation was performed by mixing maize seeds with the nitrobien using Arabic gum as adhesive material. The coated seeds were then air dried in shade for $30 \mathrm{~min}$ and the seeds were sown immediately in pots and irrigated with one tenth strength modified Hoagland solution. In the fourth group the seeds were inoculated with $\mathrm{N}-\mathrm{Bio}$ and irrigated with one tenth strength modified Hoagland solution supplemented with 2 and $10 \mathrm{~m} M \mathrm{CdSO}_{4}$. The pots were placed in an environmentally controlled growth chamber under a 16-h photoperiod at an irradiance of about $23 \mu \mathrm{mol}$ $\mathrm{m}^{-2} \mathrm{~s}^{-1}$ (cool white fluorescent tubes) and $31 / 28 \pm 2{ }^{\circ} \mathrm{C}$ light/dark temperature and irrigated with the treatment solutions every two-day interval throughout the whole experimental period. After 21 days, homologous plants were harvested, washed thoroughly from adhering soil particles, gently plotted, dissected to shoots and roots and quickly saved for estimation of the various growth parameters and chemical analyses. All chemical analyses were performed on roots and leaves.

\section{Growth parameters}

The roots and leaves were separated and taken for determination of fresh (FM) and dry biomass (DM). Shoot height was measured.

\section{Light and scanning electron microscopy}

The fragments of Zea mays L. (cv. Nevertity) roots from control and treated samples were fixed in a mixture of $2 \%$ formaldehyde and $2.5 \%$ glutaraldehyde in cacodylate buffer 
at $\mathrm{pH} 7.4$ for $2 \mathrm{~h}$, thoroughly washed in the same buffer and then post fixed with $1.0 \%(\mathrm{w} / \mathrm{v})$ osmium tetraoxide in the same buffer for $2 \mathrm{~h}$ at room temperature. Subsequently, the samples were transferred to re-distilled water and stained with a $0.5 \%$ aqueous solution of uranyl acetate. After passing through increasing concentrations of ethanol and embedded in Spurr's resin at $70^{\circ} \mathrm{C}$ (Spurr 1969). Semi-thin sections $(1 \mu \mathrm{m})$ were observed with light microscope (Olympus, Japan) after staining with 2\% uranyl acetate and lead acetate solutions (Venable and Coggeshall 1965). Samples preparation, visualization and photographing were carried out at the Electron Microscopic Unit, Faculty of Science, Alexandria University.

\section{Scanning electron microscopy}

Small pieces of fresh specimens of maize leaves from both control and treated samples were removed and fixed by immersing immediately in $4 \mathrm{~F} 1 \mathrm{G}$ in phosphate buffer solution $(\mathrm{pH} 7.2)$ at $4^{\circ} \mathrm{C}$ for $3 \mathrm{~h}$. Specimens were then post fixed in $2 \% \mathrm{OSO}_{4}$ in the same buffer at $4^{\circ} \mathrm{C}$ for $2 \mathrm{~h}$. Samples were washed in the buffer and dehydrated at $4^{\circ} \mathrm{C}$ through a graded series of ethanol. The samples were then dried by means of the critical point method, mounted using carbon paste on an Al-stub and coated with gold up to a thickness of 400A in a sputter-coating unit (JFC-1100 E). Observations of leaf morphology in the coded specimens were performed in a Jeol JSM-5300 scanning electron microscope operated between 15 and $20 \mathrm{KeV}$.

\section{Estimation of photosynthetic pigments and quantum yield of PSII (Fv/Fm)}

The photosynthetic pigments were determined according to methods described by Moran (1982) using N, N-dimethyl formamide (DMF). Absorbance was measured at two wavelengths of 646.8 and $663.8 \mathrm{~nm}$ using spectrophotometer (JENWAY, 6305, UV/Vis). Measurement of chlorophyll fluorescence was performed with OS-30P pulse modulated chlorophyll fluorimeter (Opti-sciences, Hudson, and USA) following the procedure described by Kooten and Snel (1990).

\section{Estimation of lipid peroxidation and $\mathrm{H}_{2} \mathrm{O}_{2}$ content}

Hydrogen peroxide content was determined according to the method of Velikova and Loreto (2005). The tissue was homogenized in $0.1 \%$ (w/v) TCA, $0.5 \mathrm{~mL}$ of the supernatant was mixed with $0.5 \mathrm{~mL}$ of $10 \mathrm{~m} M$ potassium phosphate buffer ( $\mathrm{pH} 7.0$ ) and $1 \mathrm{~mL}$ of $1 M \mathrm{KI}$, and the absorbance was read at $390 \mathrm{~nm}$. Lipid peroxidation was monitored by spectrophotometric determination of malondialdehyde (MDA) using thiobarbituric acid (TBA) as described in Wang et al. (2009). The content of MDA was calculated on a fresh weight basis using the following formula:

MDA $\left(\mu \mathrm{mol} \mathrm{g}^{-1} \mathrm{FM}\right)=\left[6.45\left(\mathrm{OD}_{532}-\mathrm{OD}_{600}\right)-0.56\left(\mathrm{OD}_{450}\right) \times 1000\right] / \mathrm{wt}$.
Estimation of total carbohydrate, total protein, nitrate and ammonia contents

The quantification of total available carbohydrate (TAC) was done following Murata et al. (1968). About $100 \mathrm{mg}$ of finely powdered oven-dry plant material was hydrolyzed using $0.7 \mathrm{~N} \mathrm{HCl}$ then assayed as glucose by phenol sulphoric acid method (Dubois et al. 1956). Absorbance was read at $490 \mathrm{~nm}$ using a UV-Vis Spectrophotometer (JENWAY, 6305, UV/Vis) with reference to known concentration of glucose.

Total protein (TP) content was determined according to the method of Hatree (1972) using Folin-phenol reagent. Absorbance was recorded spectrophotometrically at $650 \mathrm{~nm}$ using bovine serum albumin as a standard.

Nitrate contents were measured from an aqueous extraction of $0.2 \mathrm{~g}$ dried leaves or roots in $10 \mathrm{~mL}$ Milliporefiltered water. A 5-mL aliquot was dried in an air-drying oven at $60^{\circ} \mathrm{C}$ to complete dryness, after which $2 \mathrm{~mL}$ of the phenoldisulphonic acid reagent were added, the absorbance of the solution was measured with a spectrophotometer at $420 \mathrm{~nm}$ according to Johnson and Ulrich (1950)

Ammonium was extracted by homogenizing leaf and root segments in borate buffer $(\mathrm{pH} 8)$ containing $1.0 \%$ acetic acid. The homogenate was centrifuged for $10 \mathrm{~min}$ at $16000 \times \mathrm{g}$ and the supernatant was used for determination of ammonium using phenol-hypochlorite method as described by Solorzano (1969) Absorbance was measured at $630 \mathrm{~nm}$ with reference to known concentrations of ammonium sulphate.

\section{Nitrogen assimilating enzymes Assay}

Nitrate reductase (NR, E.C. 1.6.6.1) was extracted and assayed following the method adopted by Saber et al. (1989). Fresh plant material (leaves or roots) was homogenized in $0.05 \mathrm{M}$ Tris $-\mathrm{HCl} \mathrm{pH} 7.5$ followed by the addition of potassium nitrate and incubation at $30^{\circ} \mathrm{C}$ for 2 min. The reaction was started by addition of $0.6 \mu \mathrm{mol}$ NADH.H and allowed to proceed for $15 \mathrm{~min}$ at $30^{\circ} \mathrm{C}$, then stopped by adding $0.1 \mathrm{M}$ zinc sulphate solution and $95 \%$ ethanol. The NR activity was assayed according to the method adopted by Saber et al. (1989). The produced nitrite was estimated by measuring the absorbance at $290 \mathrm{~nm}$ and the NR specific activity was expressed as $\mu \mathrm{mol} \mathrm{NO}_{2}$ produced $\mathrm{mg}^{-1}$ protein $\mathrm{min}^{-1}$.

Glutamine synthetase (GS, EC. 6.3.1.2): was extracted as described by O’Neal and Joy (1973). Plant material was homogenized in $25 \mathrm{~m} M$ tris- $\mathrm{HCl}$ buffer $(\mathrm{pH} 7.8), 1 \mathrm{~m} M$ $\mathrm{MgCl}_{2}, 14 \mathrm{~m} M \beta$-mercaptoethanol and $1 \%(\mathrm{w} / \mathrm{v})$ polyvinyl pyrrolidone (PVP). GS specific activity was determined using hydroxylamine as substrate and the formation of $\gamma$ glutamylhydroxamate $(\gamma-\mathrm{GHM})$ was determined colorimetrically at $540 \mathrm{~nm}$ after complexion with acidified ferric chloride (Canovas et al. (1991). The GS specific activity was expressed in $\mu$ mol glutamyl hydroxamate $\mathrm{mg}^{-1}$ protein $\min ^{-1}$. 
The NADH-dependent glutamate dehydrogenase (NADH-GDH, EC.1.4.1.2) was extracted according to Turano et al. (1996). Frozen samples were homogenized using a cold mortar and pestle with grinding medium consisting of $100 \mathrm{~m} M$ Tris- $\mathrm{HCl}(\mathrm{pH} 7.5), 14 \mathrm{~m} M \beta$ mercaptoethanol and 1\% (w/v) PVP. NADH-GDH specific activity assays were carried out according to Groat and Vance (1981). The oxidation of NADH was measured by a UV-vis Spectrophotometer (TU-1901, Purkinje General, Beijing, China) at $340 \mathrm{~nm}$ for $7-10 \mathrm{~min}$ and the specific activity of GDH in units of $\mu \mathrm{mol}$ of NADH oxidized $\mathrm{mg}^{-1}$ protein $\min ^{-1}$ was calculated using an extinction coefficient for $\mathrm{NADH}$ at $340 \mathrm{~nm}$.

\section{High-performance liquid chromatography (HPLC) analysis}

Plant phytohormons: Endogenous phythormones, namely auxins (as Indole-3-butyric acid), abscisic acid (ABA) and gibberellic acid (as $\mathrm{GA}_{3}$ ) were estimated by HPLC. The plant roots and leaves $(1 \mathrm{~g})$ were thoroughly extracted in $80 \%$ methanol containing $0.1 \%$ butylhydroxytoluene (Kettner and Dorffling 1995). The extract was centrifuged at $5000 \mathrm{~g}$ for $5 \mathrm{~min}$ at $4^{\circ} \mathrm{C}$ and the supernatant was reduced to aqueous phase using rotary evaporator. The $\mathrm{pH}$ of aqueous phase was adjusted to 2.5-3.0 and extracted four times with half volume of ethyl acetate. The ethyl acetate was dried completely using rotary evaporator and the dried sample was re-dissolved in $1 \mathrm{~mL}$ of methanol (100\%). $50 \mu \mathrm{L}$ of methanol extract was analyzed using HPLC system (Agilent technologies 1200 series and UV/VIS detector 200 LC, U.S.A.) equipped with a 5- $\mu \mathrm{m}$ column (Exclipse XDB-18; 4.6 X $150 \mathrm{~mm}$; Brownlee). The solvent used was methanol$2 \%$ acetic acid and $\mathrm{H}_{2} \mathrm{O}(40: 20: 20)$ as the mobile phase, run isocratically at flow rate of $1 \mathrm{~mL} \mathrm{~min}^{-1}$. The detector was set at $254 \mathrm{~nm}$ for the integration of peak areas after calibration with the external standard.

Free amino acids: For estimation of free amino acids, samples were homogenized in 1:10 (w/v) glass distilled water and the homogenate was centrifuged at $5000 \mathrm{rpm}$ for 15 min at $4^{\circ} \mathrm{C}$. The supernatant was treated with methanol $1: 1(\mathrm{v} / \mathrm{v})$, centrifuged at $10,000 \mathrm{rpm}$ for $5 \mathrm{~min}$ and collected for analysis using the previously mentioned HPLC system. Free amino acids were determined as their stable OPA derivative (Williams 1986). The mobile phase consisted of Solvent A (sodium acetate buffer $\mathrm{pH}$ 6.8) and solvent B (glacial acetic acid and methanol), run isocratically at flow rate of $1 \mathrm{~mL} \mathrm{m^{-1 }}$. The detector was set at excitation 230 and emission $450 \mathrm{~nm}$ for the integration of peak areas after calibration with the external standards.

\section{Statistical analysis}

Statistical analysis of the results was carried out according to Duncan's multiple range tests using SPSS-20. Data were subjected to one-way ANOVA following the method of
Sokal and Rohlf (1995). Differences between treatmentmeans were considered statistically significant at $P \leq 0.05$

\section{Results}

\section{Growth parameters}

The N-Bio pretreatment enhanced the biomass accumulation of maize seedlings as well as shoot height. Increasing $\mathrm{Cd}$ concentration in the nutrient solution resulted in a significant decline of FM, DM and shoots height of NBio pretreated and untreated maize plants compared to the control; but the attained values of the former were greater than the latter (Table 1). The same trend was observed for water status of leaves and roots. At the end of the experimental period, the reduction in FM of leaves and roots of $10 \mathrm{~m} M \mathrm{Cd}$-stressed plants was 88 and $92 \%$ respectively, compared to control. The corresponding values for $\mathrm{N}-\mathrm{Bio}$ pretreatment were 68 and $78 \%$, respectively. In $10 \mathrm{~m} M \mathrm{Cd}-$ treated roots, the water content raised from 39 to $82 \%$ upon application of N-Bio. The shoot height in $10 \mathrm{~m} M \mathrm{Cd}-$ stressed maize plants in presence of $\mathrm{N}$-Bio was 3.4-fold the value of $10 \mathrm{mMCd}$-stressed ones.

\section{Light microscope of root cross sections}

Cd stress had a strong negative impact on the anatomical structure of roots in comparison to control plants (Fig. 1). The epidermal and cortical cells were severely ruptured with shrinkage and disturbance of pith parenchyma cells as well as a decrease in the diameter and number of metaxylem elements. In addition, there was a marked disorganization and crimple structures of xylem and phloem elements. Obviously, N-Bio pretreatment of maize seeds mostly improved the adverse effect of $\mathrm{Cd}$ on the root anatomical structure.

\section{Scanning electron microscope}

A clear stomatal structure in control and N-Bio-pretreated plants were observed, whereas marked variations in stomatal opening and guard cell shape were noticed in response to $\mathrm{Cd}$ stress and $\mathrm{N}-\mathrm{Bio}$ application (Fig. 2). The stomata of the $10 \mathrm{~m} M \mathrm{Cd}$ treated maize seedlings were highly defective with their completely collapsed, irregularly thickened guard cells and their stomatal opening almost remained closed. On the other hand, N-Bio- pretreatment of $\mathrm{Cd}$-stressed leaves increased the stomatal opening compared to $\mathrm{Cd}$ - stressed ones which might reveal the role of N-Bio in enhancing the $\mathrm{CO}_{2}$ diffusion.

\section{Photosynthetic pigments and photosynthetic efficiency}

Contamination of nutrient solution with various $\mathrm{Cd}$ levels significantly decreased $\mathrm{Chl} a, b$ and total photosynthetic pigments content as well as Fv/Fm values. The carotenoid 
Table 1: Effect of biofertilizer application on fresh and dry biomasses, shoot height and water content in the leaves of maize seedlings grown at 2- and 10-m Cd for $21 \mathrm{~d}$

\begin{tabular}{|c|c|c|c|c|c|c|c|c|}
\hline \multirow[t]{2}{*}{ Treatments } & \multirow[t]{2}{*}{ Cd conc. $(\mathrm{mM})$} & \multicolumn{2}{|c|}{ FM (mg plant ${ }^{-1)}$} & \multicolumn{2}{|c|}{ DM (mg plant $\left.{ }^{-1}\right)$} & \multirow[t]{2}{*}{ Shoot Height $(\mathrm{cm})$} & \multicolumn{2}{|c|}{ Water contents (\%) } \\
\hline & & Roots & Leaves & Roots & Leaves & & Roots & Leaves \\
\hline \multirow[b]{2}{*}{$-\mathrm{Bio}$} & 0 & $5.64 \pm 0.63^{\mathrm{c}}$ & $19.83 \pm 1.65^{\mathrm{c}}$ & $0.71 \pm 0.06^{\mathrm{bc}}$ & $1.75 \pm 0.13^{\mathrm{cd}}$ & $8.8 \pm 0.73^{b}$ & $87 \pm 6.69^{\mathrm{a}}$ & $91 \pm 7.00^{\mathrm{a}}$ \\
\hline & 2 & $3.95 \pm 0.40^{\mathrm{d}}$ & $14.01 \pm 1.56^{\mathrm{d}}$ & $0.64 \pm 0.05^{\mathrm{cd}}$ & $1.68 \pm 0.15^{\mathrm{de}}$ & $6.5 \pm 0.54^{\mathrm{c}}$ & $84 \pm 9.33^{\mathrm{a}}$ & $88 \pm 8.00^{\mathrm{a}}$ \\
\hline \multirow{4}{*}{+ Bio } & 0 & $12.94 \pm 1.18^{\mathrm{a}}$ & $36.57 \pm 3.32^{\mathrm{a}}$ & $1.12 \pm 0.11^{\mathrm{a}}$ & $3.71 \pm 0.37^{\mathrm{a}}$ & $15.4 \pm 1.71^{\mathrm{a}}$ & $91 \pm 8.27^{\mathrm{a}}$ & $93 \pm 8.45^{\mathrm{a}}$ \\
\hline & 2 & $9.66 \pm 0.97^{b}$ & $33.10 \pm 3.01^{\mathrm{a}}$ & $0.91 \pm 0.08^{\mathrm{ab}}$ & $2.48 \pm 0.21^{\mathrm{b}}$ & $14.2 \pm 1.29^{\mathrm{b}}$ & $91 \pm 8.27^{\mathrm{a}}$ & $93 \pm 10.33^{\mathrm{a}}$ \\
\hline & 10 & $2.75 \pm 0.23^{\mathrm{d}}$ & $11.52 \pm 0.96^{\mathrm{b}}$ & $0.49 \pm 0.03^{\mathrm{d}}$ & $1.53 \pm 0.14 \mathrm{e}$ & $6.8 \pm 0.62^{\mathrm{c}}$ & $82 \pm 9.11^{\mathrm{b}}$ & $87 \pm 9.67^{b}$ \\
\hline & $P=0.05$ & $0.003^{*}$ & $0.0087^{*}$ & $0.005^{*}$ & $0.003^{*}$ & $0.017^{*}$ & $0.039 *$ & 0.04 \\
\hline
\end{tabular}

Values are means of 3 independent replicates \pm SE. means followed by different letters are significantly different at $P \leq 0.05$ according to the least significant difference (LSD)

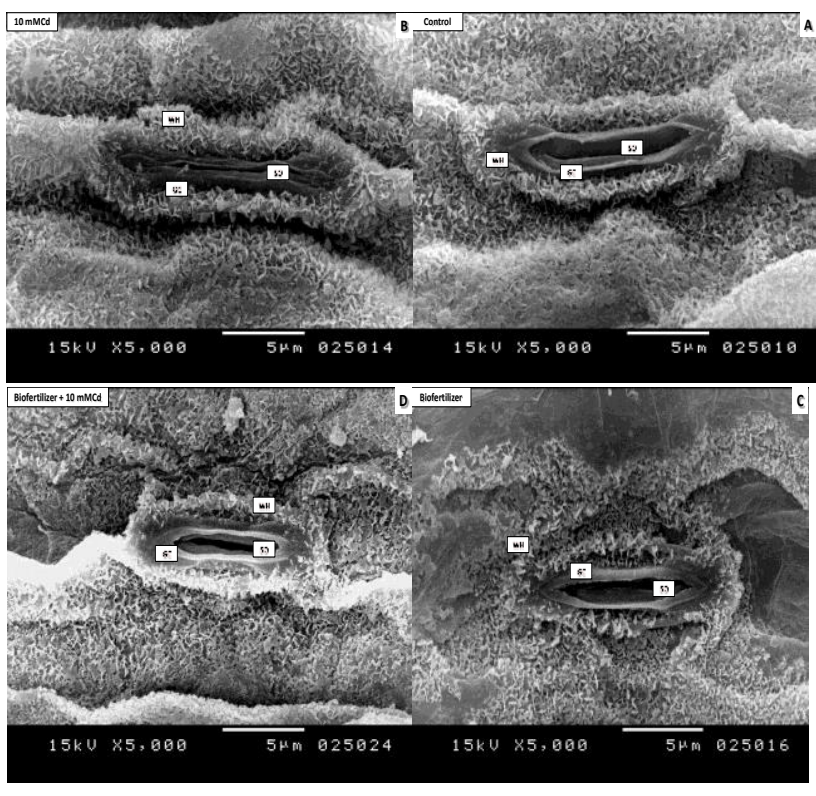

Fig. 1: Scanning electron microscopy (SEM) of abaxial leaf surface from 21-day-old maize plants in response to Cd-stress and biofertilizer application. (A): untreated control, (B): $10 \mathrm{~m} M \mathrm{Cd}$, (C): biofertilizer and (D): biofertilizer $+10 \mathrm{mM} \mathrm{Cd}$

contents were insignificantly changed compared to control (Table 2). Inoculation of maize seeds with N-Bio significantly increased total pigments content and $\mathrm{Fv} / \mathrm{Fm}$ values in Cd-stressed leaves versus those of non-inoculated ones. It is interesting to demonstrate that in absence of $\mathrm{Cd}$, inoculation of N-Bio significantly increased the photosynthetic pigments content compared to noninoculated control.

\section{$\mathrm{H}_{2} \mathrm{O}_{2}$ content and Lipid peroxidation}

After prolonged exposure of maize plants to $\mathrm{Cd}$ stress, there was a significant increment in $\mathrm{H}_{2} \mathrm{O}_{2}$ content in a concentration dependent aspect; it was about 5.4- and 4.6folds the value of control in response to $10 \mathrm{mM} \mathrm{Cd}$ in the leaves and roots, respectively (Fig. 3). Inoculation with $\mathrm{N}$ Bio resulted in a significant depression in $\mathrm{H}_{2} \mathrm{O}_{2}$ accumulation compared to non-inoculated treatment. At NBio-10 $\mathrm{m} M$ Cd- treatment, the decrease in $\mathrm{H}_{2} \mathrm{O}_{2}$ content was
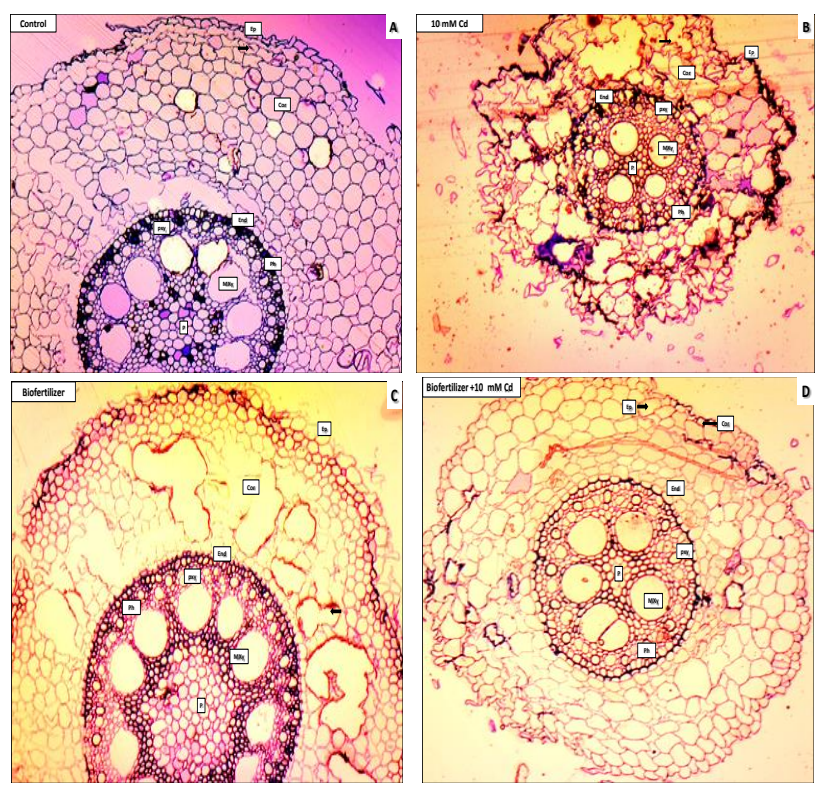

Fig. 2: Light microscope photography showing transverse sections of 21-day-old maize roots in response to Cd-stress and biofertilizer application (A): untreated control, (B): $10 \mathrm{~m} M \mathrm{Cd}$, (C): biofertilizer and (D): biofertilizer $+10 \mathrm{~m} M$ Cd. (Ep) Epidermis, (End) Endodermis, (Cor) Cortex, (Ph) Phloem, (Mxy) Metaxylem, (Pxy) Protoxylem and (P) Pith

41 and 55\% in the leaves and roots, respectively compared to the value at $10 \mathrm{~m} M \mathrm{Cd}$ alone.

In parallel with changes in $\mathrm{H}_{2} \mathrm{O}_{2}, \mathrm{Cd}$ treatment significantly increased MDA content, indicting lipid peroxidation in the leaves and roots of maize plants compared to control. However, inoculation of maize seeds with N-Bio reduced the Cd-induced MDA accumulation (Fig. 3).

\section{Carbohydrate, protein, nitrate and ammonia contents}

Increasing Cd- levels significantly reduced TAC and TP in the leaves and roots of maize seedlings (Table 3). At 10 $\mathrm{m} M \mathrm{Cd}$ treatment, the TAC content of leaves and roots were 49 and $38 \%$ of control, respectively. The corresponding values for TP were 36 and $30 \%$, respectively. The interactive effect of $\mathrm{N}-\mathrm{BiO}$ and $\mathrm{Cd}$ displayed a significant 


\section{Response of Maize to Cd Stress and Biofertilizer Application / Intl J Agric Biol, Vol 25, No 1, 2021}

Table 2: Effect of biofertilizer application on photosynthetic pigments ( $\left.\mathrm{mg} \mathrm{g}^{-1} \mathrm{FM}\right)$ and quantum yield of PSII (Fv/Fm) in the leaves of maize seedlings grown at 2- and 10-m Cd for $21 \mathrm{~d}$.

\begin{tabular}{|c|c|c|c|c|c|c|}
\hline \multirow[t]{2}{*}{ Treatments } & \multirow[t]{2}{*}{ Cd conc. $(\mathrm{m})$} & \multicolumn{4}{|c|}{ Pigment content $\left(\mathrm{mg} \mathrm{g}^{-1} \mathrm{FM}\right)$} & \multirow[t]{2}{*}{ Quantum yield of PSII $\left(\mathrm{F}_{\mathrm{V}} / \mathrm{F}_{\mathrm{M}}\right)$} \\
\hline & & Chl. $a$ & Chl. $b$ & Carot. & Total & \\
\hline \multirow[t]{3}{*}{$\overline{-B i o}$} & 0 & $22.86 \pm 2.54^{\mathrm{b}}$ & $12.08 \pm 1.10^{\mathrm{ca}}$ & $5.75 \pm 0.52^{\mathrm{d}}$ & $40.68 \pm 3.39^{\mathrm{a}}$ & $0.807 \pm 0.09^{\mathrm{a}}$ \\
\hline & 2 & $14.94 \pm 1.15^{\mathrm{c}}$ & $7.54 \pm 0.66^{d}$ & $6.40 \pm 0.71^{\mathrm{d}}$ & $28.88 \pm 2.72^{\mathrm{c}}$ & $0.730 \pm 0.08^{b c}$ \\
\hline & 10 & $5.12 \pm 0.47^{\mathrm{d}}$ & $2.38 \pm 0.20^{\mathrm{d}}$ & $7.46 \pm 0.42^{\text {cd }}$ & $14.96 \pm 1.08^{\mathrm{d}}$ & $0.562 \pm 0.04^{\mathrm{d}}$ \\
\hline \multirow[t]{4}{*}{+ Bio } & 0 & $34.92 \pm 2.49^{\mathrm{a}}$ & $10.03 \pm 0.63^{\mathrm{b}}$ & $9.56 \pm 0.87^{\mathrm{bc}}$ & $54.51 \pm 6.06^{\mathrm{a}}$ & $0.815 \pm 0.07^{\mathrm{a}}$ \\
\hline & 2 & $28.78 \pm 3.20^{\mathrm{ab}}$ & $14.22 \pm 1.19^{\mathrm{ac}}$ & $10.79 \pm 0.98^{\mathrm{bc}}$ & $53.79 \pm 4.48^{\mathrm{a}}$ & $0.780 \pm 0.07^{b}$ \\
\hline & 10 & $12.63 \pm 1.64^{\mathrm{c}}$ & $6.60 \pm 0.96^{\mathrm{d}}$ & $17.54 \pm 1.75^{\mathrm{a}}$ & $36.77 \pm 4.25^{\mathrm{b}}$ & $0.721 \pm 0.07^{\mathrm{c}}$ \\
\hline & $P=0.05$ & $0.019 *$ & $0.009 *$ & $0.035^{*}$ & $0.028 *$ & $0.007 *$ \\
\hline
\end{tabular}

Values are means of 3 independent replicates \pm SE. means followed by different letters are significantly different at $P \leq 0.05$ according to the least significant difference (LSD)

Table 3: Effect of biofertilizer application on nitrate $\left(\mathrm{mg} \mathrm{g}^{-1} \mathrm{DM}\right)$, ammonium $\left(\mu \mathrm{g} \mathrm{g}^{-1} \mathrm{DM}\right)$, total available carbohydrates ( $\left.\mathrm{mg} \mathrm{g}^{-1} \mathrm{DM}\right)$ and total protein contents $\left(\mathrm{mg} \mathrm{g}^{-1} \mathrm{DM}\right)$ in the leaves and roots of maize seedlings grown at 2- and 10-m $M \mathrm{Cd}$ for $21 \mathrm{~d}$.

\begin{tabular}{|c|c|c|c|c|c|c|c|c|c|}
\hline \multirow[t]{2}{*}{ Treatments } & \multirow[t]{2}{*}{ Cd conc. $(\mathrm{m} M)$} & \multicolumn{2}{|c|}{$\mathrm{NO}_{3}{ }^{-}$content $\left(\mathrm{mg}^{-} \mathrm{g}^{-1} \mathrm{DM}\right)$} & \multicolumn{2}{|c|}{$\mathrm{NH}_{4}^{+}$content $\left(\mu \mathrm{g} \mathrm{g}^{-1} \mathrm{DM}\right)$} & \multicolumn{2}{|c|}{ TAC $\left(\mathrm{mg} \mathrm{g}^{-1} \mathrm{DM}\right)$} & \multicolumn{2}{|c|}{$\mathrm{TP}\left(\mathrm{mg} \mathrm{g}^{-1} \mathrm{DM}\right)$} \\
\hline & & Roots & Leaves & Roots & Leaves & Roots & Leaves & Roots & Leaves \\
\hline \multirow[t]{3}{*}{-Bio } & 0 & $1.50 \pm 0.045^{\mathrm{a}}$ & $2.53 \pm 0.281^{\mathrm{c}}$ & $3.38 \pm 0.307^{d}$ & $10.74 \pm 1.193^{\mathrm{dc}}$ & $66.79 \pm 6.07^{b}$ & $91.32 \pm 10.15^{b}$ & $19.43 \pm 1.49^{b}$ & $42.51 \pm 4.72^{\mathrm{bc}}$ \\
\hline & 2 & $0.82 \pm 0.047^{\mathrm{c}}$ & $1.74 \pm 0.158^{\mathrm{d}}$ & $12.64 \pm 1.149^{c}$ & $21.16 \pm 1.924^{\mathrm{c}}$ & $62.69 \pm 5.70^{b}$ & $81.08 \pm 9.01^{\mathrm{c}}$ & $16.91 \pm 1.30^{\mathrm{c}}$ & $37.88 \pm 3.16^{\mathrm{cd}}$ \\
\hline & 10 & $0.38 \pm 0.072^{\mathrm{e}}$ & $0.48 \pm 0.051^{\mathrm{f}}$ & $54.06 \pm 5.691^{\mathrm{a}}$ & $77.22 \pm 8.128^{\mathrm{a}}$ & $25.47 \pm 1.96^{\mathrm{d}}$ & $45.04 \pm 4.50^{\mathrm{d}}$ & $5.76 \pm 0.58^{d}$ & $15.16 \pm 1.26^{\mathrm{e}}$ \\
\hline \multirow[t]{4}{*}{$+\mathrm{Bio}$} & 0 & $1.48 \pm 0.053^{\mathrm{a}}$ & $4.59 \pm 0.399^{\mathrm{a}}$ & $4.21 \pm 0.468^{\mathrm{d}}$ & $6.08 \pm 0.676^{\mathrm{f}}$ & $74.65 \pm 6.22^{\mathrm{a}}$ & $101.65 \pm 8.47^{\mathrm{a}}$ & $24.64 \pm 2.46^{\mathrm{a}}$ & $51.11 \pm 4.26^{\mathrm{a}}$ \\
\hline & 2 & $1.09 \pm 0.041^{\mathrm{b}}$ & $3.06 \pm 0.269^{b}$ & $6.99 \pm 0.583^{\mathrm{cd}}$ & $8.83 \pm 0.803^{\text {ef }}$ & $73.52 \pm 7.35^{\mathrm{a}}$ & $94.57 \pm 7.88^{b}$ & $23.26 \pm 2.11^{\mathrm{a}}$ & $48.38 \pm 4.03^{\mathrm{a}} \mathrm{b}$ \\
\hline & 10 & $0.55 \pm 0.058^{\mathrm{d}}$ & $1.06 \pm 0.112^{\mathrm{c}}$ & $25.36 \pm 2.669^{b}$ & $35.56 \pm 3.743^{b}$ & $42.52 \pm 3.54^{\mathrm{c}}$ & $78.32 \pm 6.02^{c}$ & $12.53 \pm 1.14^{\mathrm{c}}$ & $32.27 \pm 3.23^{\mathrm{d}}$ \\
\hline & $P=0.05$ & $0.001 *$ & $0.003^{*}$ & $0.010^{*}$ & $0.009 *$ & $0.017 *$ & $0.011^{*}$ & $0.025^{*}$ & $0.009^{*}$ \\
\hline
\end{tabular}

Values are means of 3 independent replicates \pm SE. means followed by different letters are significantly different at $P \leq 0.05$ according to the least significant difference (LSD)

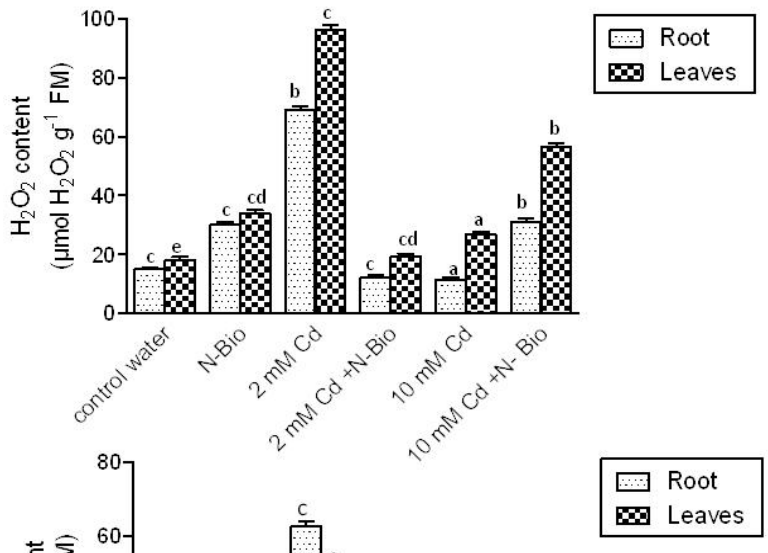

2.1-folds, respectively compared to those of non-inoculated ones. The corresponding values in roots were 1.9 - and 2.5 folds, respectively.

Supplementing the nutrient solution with various $\mathrm{Cd}$ levels significantly suppressed $\mathrm{NO}_{3}{ }^{-}$content in leaves and roots of maize plants either pretreated or untreated with $\mathrm{N}$ Bio, compared to their controls; but attained values of the latter were markedly higher than the former (Table 3 ). The increase in the $\mathrm{NO}_{3}{ }_{3}$ content in the leaves and roots of N-Bio inoculated plants grown at $10 \mathrm{~m} M \mathrm{Cd}$ was 121 and $45 \%$ compared to those of non inoculated ones.

Conversely to the $\mathrm{NO}_{3}{ }^{-}$trend, there was a marked accumulation of $\mathrm{NH}_{4}{ }^{+}$content in leaves and roots of maize plants with increasing $\mathrm{Cd}$ concentrations in growth media in absence or presence of the N-Bio, but the attained values in the latter were lower than those in the former. On the other hand, N-Bio- pretreatment of Cd-stressed plants decreased the $\mathrm{NH}_{4}{ }^{+}$accumulation under $\mathrm{Cd}$ stress. The $\mathrm{NH}_{4}{ }^{+}$content in leaves and roots of N-Bio-10 $\mathrm{m} M$ Cd-treated plants decreased by 54 and $53 \%$, respectively compared to N-Biopretreated plants alone.

\section{Changes in phytohormones and free individual amino acids}

Fig. 3: Effect of N-biofertilizer application on hydrogen peroxide $\left(\mathrm{H}_{2} \mathrm{O}_{2}\right)$ and malondialdehyde (MDA) in the roots and leaves of maize seedlings grown at 2- and $10-\mathrm{m} M \mathrm{Cd}$ for $21 \mathrm{~d}$

Values are means of 3 independent replicates \pm SE. means followed by differen letters are significantly different at $P \leq 0.05$ according to the least significant difference (LSD)

increment in TAC and TP contents compared to those of $\mathrm{Cd}$ treated-plants. The TAC and TP contents in N-Bio inoculated leaves in presence of $10 \mathrm{mMCd}$ were 1.7 - and

The $10 \mathrm{~m} M \mathrm{Cd}$ stress brought about significant decline of IAA and $\mathrm{GA}_{3}$ contents in leaves and roots of N-Bio inoculated and non-inoculated maize plants, whereas ABA significantly increased in comparison to controls (Table 4). The decrease of IAA and $\mathrm{GA}_{3}$ contents in leaves of $\mathrm{Cd}$ stressed plants were 49 and $66 \%$ respectively compared to the control. The corresponding values for roots were 66 and $44 \%$ respectively. Contrarily, the increase of $\mathrm{ABA}$ in leaves 
Table 4: Effect of biofertilizer application on plant phytohormons ( $\left.\mathrm{ng} \mathrm{g}^{-1} \mathrm{FM}\right)$ in the leaves and roots of maize seedlings grown at 2- and 10-mM Cd for 21 d. (ABA): Abscisic acid; (IAA): indole acetic acid and ( $\left.\mathrm{GA}_{3}\right)$ : gibberellic acid.)

\begin{tabular}{|c|c|c|c|c|c|c|c|}
\hline \multirow[t]{3}{*}{ Treatment } & \multirow[t]{3}{*}{ Cd conc. $(\mathrm{mM})$} & \multicolumn{6}{|c|}{ Hormone Content (ng g $\left.{ }^{-1} \mathrm{FM}\right)$} \\
\hline & & \multicolumn{2}{|c|}{ IAA } & \multicolumn{2}{|r|}{$\mathrm{GA}_{3}$} & \multicolumn{2}{|c|}{$\mathrm{ABA}$} \\
\hline & & Roots & Leaves & Roots & Leaves & Roots & Leaves \\
\hline \multirow[t]{2}{*}{- Bio } & 0 & $18.14 \pm 1.64^{\mathrm{b}}$ & $22.05 \pm 2.20^{c}$ & $36.15 \pm 3.27^{\mathrm{c}}$ & $48.11 \pm 4.80^{c}$ & $9.09 \pm 0.75^{\mathrm{c}}$ & $10.08 \pm 0.83^{\mathrm{c}}$ \\
\hline & 10 & $6.22 \pm 0.46^{\mathrm{c}}$ & $11.30 \pm 0.92^{\mathrm{d}}$ & $20.10 \pm 2.00^{\mathrm{d}}$ & $16.21 \pm 1.33^{\mathrm{d}}$ & $23.06 \pm 1.92^{\mathrm{a}}$ & $35.10 \pm 3.89^{\mathrm{a}}$ \\
\hline \multirow[t]{3}{*}{$+\mathrm{Bio}$} & 0 & $31.11 \pm 2.38^{\mathrm{a}}$ & $46.09 \pm 4.18^{\mathrm{a}}$ & $51.14 \pm 5.67^{\mathrm{a}}$ & $106.11 \pm 10.60^{\mathrm{a}}$ & $9.09 \pm 0.75^{\mathrm{c}}$ & $11.11 \pm 1.00^{\mathrm{b}}$ \\
\hline & 10 & $17.09 \pm 1.31^{\mathrm{b}}$ & $32.12 \pm 2.91^{\mathrm{b}}$ & $44.12 \pm 4.00^{\mathrm{b}}$ & $70.10 \pm 7.78^{\mathrm{b}}$ & $16.08 \pm 1.60^{\mathrm{b}}$ & $16.10 \pm 1.78^{\mathrm{b}}$ \\
\hline & $P$ & $0.021^{*}$ & $0.029 *$ & $0.012 *$ & $0.009 *$ & $0.015^{*}$ & $0.011 *$ \\
\hline
\end{tabular}

Values are means of 3 independent replicates \pm SE. means followed by different letters are significantly different at $P \leq 0.05$ according to the least significant difference (LSD)

Table 5: Effect of biofertilizer application on free individual amino acid content (mg $\left.100 \mathrm{~g}^{-1} \mathrm{DM}\right)$ in the roots and leaves of maize seedlings grown at 2- and $10-\mathrm{m} M \mathrm{Cd}$ for $21 \mathrm{~d}$.

\begin{tabular}{lllll}
\hline $\begin{array}{l}\text { Amino acids } \\
\left(\mathrm{mg} 100 \mathrm{~g}^{-1} \mathrm{DM}\right)\end{array}$ & Control & Bio & $10 \mathrm{~m} M \mathrm{Cd} 10 \mathrm{~m} M+$ Bio \\
\hline Aspartic acid & 1.49 & 2.07 & 2.46 & 3.00 \\
Glutamic acid & 1.98 & 5.40 & 0.61 & 3.43 \\
Glutamine & 1.16 & 0.88 & 0.07 & 0.19 \\
Arginine & 1.35 & 1.17 & 2.31 & 1.02 \\
Lysine & 1.19 & 0.98 & 0.38 & 0.33 \\
Alanine & 0.34 & 0.95 & 0.16 & 1.29 \\
Glycine & 0.34 & 0.72 & 0.04 & 0.34 \\
Isoleucine & 0.23 & 0.47 & 0.12 & 0.17 \\
Leucine & 1.45 & 1.06 & 0.57 & 0.87 \\
Serine & 0.19 & 0.92 & 0.10 & 0.13 \\
Theronine & 1.39 & 4.51 & 0.23 & 2.63 \\
Tyrosine & 0.58 & 0.18 & 0.34 & 0.46 \\
Phenylalanine & 0.51 & 1.20 & 1.40 & 0.33 \\
Methionine & 0.41 & 0.37 & 0.15 & 1.20 \\
Cysteine & 0.34 & 0.44 & 0.09 & 0.32 \\
Tryptophan & 1.44 & 3.46 & 0.17 & 0.98 \\
Total & 14.39 & 24.78 & 9.02 & 16.69 \\
\hline
\end{tabular}

and roots of $10 \mathrm{~m} M$ Cd-stressed maize plants was 248 and $154 \%$ compared to control, respectively. N-Bio pretreatment alone or in combination with $\mathrm{Cd}$ stress had a stimulatory effect on the endogenous IAA and $\mathrm{GA}_{3}$ while it decreased the $\mathrm{ABA}$ content, compared to their respective controls.

Among 16 detected free amino acids, $10 \mathrm{mM} \mathrm{Cd}$ resulted in a marked increase in arginine (Arg, 71\%), aspartic acid (Asp, 65\%) and phenylalanine (Phe, 176\%) compared to control (Table 5). Other amino acids were markedly decreased such as glutamic acid (Glut, 69\%), glycine (Gly, 88\%) and cysteine (Cys, 74\%). Application of $\mathrm{N}$-Bio in presence of $10 \mathrm{~m} M-\mathrm{Cd}$ mainly led to suppression in the level of 3 amino acids namely Arg, Lyc and Phe while the other detected amino acids were markedly increased compared to non-inoculated Cd-stressed leaves.

\section{Enzyme activities}

Generally, prolonged exposure to $\mathrm{Cd}$-stress in presence or absence of N-Bio significantly decreased both NR and GS specific activity in leaves and roots of maize plants in comparison to their controls (Fig. 4). The decrease of NR and GS specific activity in severely Cdstressed leaves was 79 and $75 \%$, respectively compared

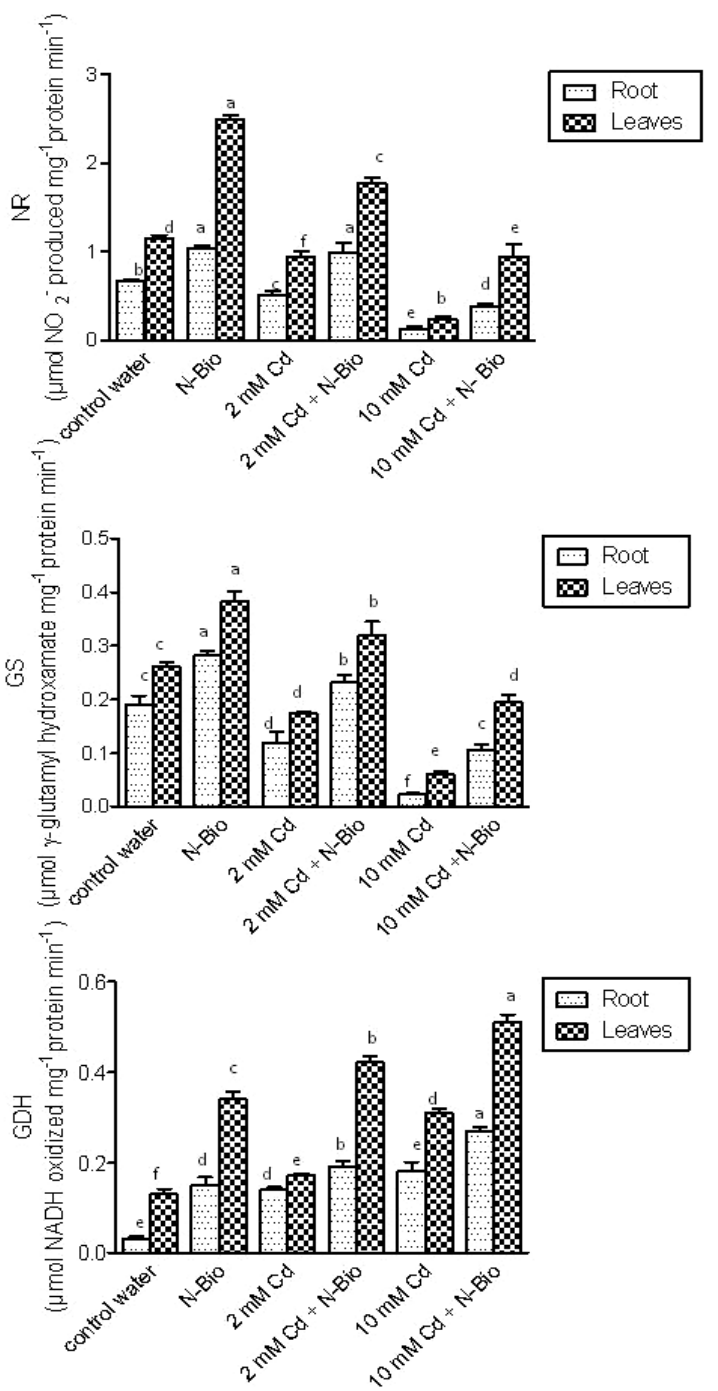

Fig. 4: Effect of N-biofertilizer application on NR, GS and GDH specific activities in the roots and leaves of maize seedlings grown at 2- and $10-\mathrm{m} M \mathrm{Cd}$ for $21 \mathrm{~d}$

Values are means of 3 independent replicates \pm SE. means followed by different letters are significantly different at $P \leq 0.05$ according to the least significant difference (LSD)

to control. The corresponding values for roots were 81 and $88 \%$, respectively. The same trend was observed upon $\mathrm{N}$-Bio pretreatment but the attained values for both NR and 
GS specific activities were much less than in Cd-treated plants.

In contrast to NR and GS trends, contaminating the nutrient media with various Cd levels significantly increased GDH specific activity in leaves and roots of N-Biountreated or treated maize plants (Fig. 4). At $10 \mathrm{mM} \mathrm{Cd}$ stress, the GDH specific activity in leaves and roots was 2.3and 6-folds respectively, compared to untreated control. The corresponding values in N-Bio-pretreated leaves and roots were 1.5 - and 1.8-folds, respectively.

\section{Discussion}

Cd-stress negatively influenced several growth parameters of maize plants. Several studies have shown that growth biomarkers have been depressed due to Cd-stress in a number of plants including Solanum melongena L. (Singh and Prasad 2014) and Zea mays L. (Liu et al. 2007). It has been reported that increasing $\mathrm{Cd}$ accumulation in plant organs could enhance the generation of ROS which caused the damage of plasma membranes, photosynthetic pigments, and various cellular components, leading to reduction of growth (Liu et al. 2007). In accordance with these views, the current study demonstrated that $\mathrm{Cd}$ stress induced a significant accumulation of $\mathrm{H}_{2} \mathrm{O}_{2}$ and MDA in leaves and roots of maize plants and disturbed the root anatomical structure causing immature xylogenesis and dysfunctions of phloem which reflect the decrease of water and photosynthates allocation. Moreover, the disturbance of the anatomical feature of maize roots was accompanied with a marked accumulation of $\mathrm{Cd}$ in roots (Data not shown) and a significant decline of IAA and $\mathrm{GA}_{3}$ contents indicating the inhibitory effect of $\mathrm{Cd}$ on auxins biosynthesis and disordering the mitotic divisions leading to suppression of cell divisions and elongation and hence the growth. Soudeh and Zarinkamar (2012) reported that inhibition of root growth may be the result of decreased cell division and or disorderliness in the activity and contents of phytohormones like auxins in response to heavy metals stress. Cd-stress seems to provoke a series of structural alterations with possible functional implications in the maize plant such as shrinkage of root diameter ( $\mathrm{Li}$ et al. 2014) and reduction in the metaxylem vessels diameter (Gowayed and Almaghrabi (2013) which is considered as important factor affecting root capacity as translocation conduits.

Comstock (2002) reported that the regulation of guard cell has become a crucial model system for explaining the regulatory signals that control stomatal behavior. $\mathrm{Cd}$ exposure profoundly alters the behavior of stomata in maize leaves (Fig. 1). Similar observations were reported for many plant species grown under different heavy metals stress (Mondal et al. 2013; Divyajyothi and Sujatha 2019). The defective stomata probably might have lost a functional closing mechanism, and therefore were unable to regulate the exchange of water vapor and $\mathrm{CO}_{2}$, which decreases both transpiration and photosynthesis (Fatemy et al. 1985).
Furthermore, this adverse stomatal closure may be due to the loss of turgor of the guard cells and the damage to the guard subsidiary cells (Priyadarshini and Sujatha 2011).

In the present study, Cd stress triggered a significant reduction in the photosynthetic pigments content and the quantum yield of PSII $\left(\mathrm{F}_{\mathrm{v}} / \mathrm{F}_{\mathrm{m}}\right)$. These observations are in accordance with those reported for coriander (Haneef $e t$ al. 2013) and tomato (Singh and prasad 2017). The suppression in photosynthetic pigments content has been reported to be related to the inhibitory effect of $\mathrm{Cd}$ on specific enzymes responsible for their synthesis and induction of some degradative enzymes such as chlorophyllase as well as destruction of the photosynthetic machinery and reduction in the chlorophyll proteins content (Singh and Prasad 2017). In addition, Singh and Prasad (2014) suggested that the decrease of Fv/Fm values in plants under $\mathrm{Cd}$ stress could be related to the decline in the active reaction centers and inability of PSII to reduce the primary acceptor (QA) resulting in a decrease of electron transport and photosynthetic activity. Therefore, the decline of chlorophyll contents in Cd-stressed maize plants could be related to the enhancement of lipid peroxidation of thylakoids and chloroplast membranes as indicated by increasing MDA content in the leaves. Moreover, the decrease of TP content, due to increase of oxidative stress by generated $\mathrm{ROS}\left(\mathrm{H}_{2} \mathrm{O}_{2}\right)$ might inhibit the biosynthesis and content of pigment-protein complexes of photosystems, hence reduce the photosynthetic activity and growth.

The results of this study apparently demonstrated that N-Bio pretreatment significantly increased the growth of Cd-stressed maize plants. Fukami et al. (2017) reported that spraying cells or metabolites of Azosperillum brasilense AbV5 and Ab-V6 enhanced the growth of maize plants. Gothandapani et al. (2017) have reported that application of various plant growth promoting microorganisms (PGPMs) induces the growth biomarkers in several plants. Earlier, Sokhangoy et al. (2012) concluded that biofertilizers might enhance the nutrient availability to plants causing an increase of growth. Whereas, Etesami (2018) suggested that secretion of plant hormones (e.g., IAA) by biofertilizers might induce the plant growth. Therefore, the increase of growth biomarkers in N-Bio-pretreated maize plants under $\mathrm{Cd}$ stress could be attributed to increasing the absorption of plant hormones (IAA) and nutrients including $\mathrm{NO}_{3}$ from the rhizophere. Data recoded in this study (Table 3 and 4) pointed out that, there was a marked increase of $\mathrm{NO}_{3}^{-}$content and plant growth regulators (IAA and GA3) in leaves and roots of N-Bio-pretreated maize plants under $\mathrm{Cd}$ stress in comparison to untreated ones. These observations were accompanied with a marked increase of TAC and TP contents, revealing the stimulation of growth. Several studies in Eruca sativa (Kamran et al. 2015) and Zea mays (Roychowdhury et al. 2017) grown under $\mathrm{Cd}$ stress showed a marked reduction in growth in response to $\mathrm{Cd}$ stress, while PGPR application could contribute to improved growth indices. 
Furthermore, N-Bio treatment markedly increased the photosynthetic pigment contents and $\mathrm{Fv} / \mathrm{Fm}$ ratio of $\mathrm{Cd}$ treated maize leaves compared to non-treated plants. Similarly, Khanna et al. (2019) found that plant growth promoting microorganism's inoculation resulted in an increase of photosynthesis and growth of Cd-stressed tomato plants. The findings in this study might be explained by decreasing the generation of ROS and oxidative damage of chloroplasts and thylakoids membranes and enzymatic proteins as well as increasing the availability of essential elements introducing in chlorophyll biosynthesis (as indicated by the increase of $\mathrm{NO}_{3}$ content). Moreover, inoculation of maize seeds with $\mathrm{N}$-Bio significantly declined ABA content that was associated with an increase of stomatal opening. These observations might reflect the increase of $\mathrm{CO}_{2}$ diffusion and hence increase photosynthesis. Haneef et al. (2013) reported that PGPMs are capable of shifting off the toxic effect of heavy metals through enhancing the mobilization of elements such as $\mathrm{N}$, $\mathrm{K}, \mathrm{P}, \mathrm{Mg}$ and Fe.

Nitrogen $(\mathrm{N})$ is one of the essential nutrients involved in biosynthesis of various cell components such as amino acids, protein and chlorophylls that reflect its essential role in sustaining the growth of plants. Decreased TP content in the maize plants grown on excess $\mathrm{Cd}$ was in accordance with earlier observations in several plants such as chamomile plants (Kovacik and Backor 2017). It has been reported that the decrease of protein content under Cd stress may be related to enhancement of protein hydrolysis and/or decrease of protein synthesis in addition to the suppression in amino acids biosynthesis (Xu et al. 2012). It can be suggested that the decrease of TP content in Cd-stressed maize plants, in this study, might be attributed to increasing ROS generation, as indicated by increase of $\mathrm{H}_{2} \mathrm{O}_{2}$ accumulation, which cause oxidative damage for protein. Moreover, the decrees of C-skeleton, due to decline of TAC and inhibition of $\mathrm{NO}_{3}{ }^{-}$uptake and its assimilation, via $\mathrm{NR}$ and GS (Fig. 4), could result in a marked decrease of amino acids biosynthesis and hence protein synthesis.

It is well documented that plants exposed to different abiotic stresses modulate total and amino composition (Zemanová et al. 2017). The findings in this study indicated an increase of some amino acids while others were decreased. These variations might reveal the participation of various amino acids in the biosynthesis of secondary metabolites involved in strategy mechanism (Chaffei et al. 2004; Xu et al. 2012). The decrease of arginine and phenylalanine could be involved in the biosynthesis of polyamine and phenolic compounds, while the decrease of methionine, cysteine, glutamic and glycine content might be introduced in the synthesis of phytochelatine and thiol compounds such as GSH and thiol-non proteins. On the other hand, the decrease of tryptophan content might reflect the suppression of IAA concentration in Cd-stressed maize plants. Costa and Spitz (1997) reported that increasing of asparagine accumulation in Cd-treated in vitro lupin tissues culture could participate in the synthesis of chelate peptide for detoxification of the $\mathrm{Cd}$ toxicity. It is interesting to demonstrate that methionine content decreased markedly in $10 \mathrm{~m} M$ Cd-stressed plants while it increased upon application of N-Bio compared to stressed non-inoculated plants. These findings might reflect the role of N-Bio in the protection of maize growth from the inhibitory effect of ethylene via secreting of 1-amino cyclopropane 1carboxylate (ACC). Ahmad et al. (2013) reported that NBio can produce several protective enzymes such as ACC deaminase. Kang et al. (2010) postulated that ACC, the precursor of ethylene is synthesized from methionine via ACC synthase activity, and then produced ethylene could inhibit the growth. Thus, the decreased methionine content in Cd-treated leaves, in this study, was accompanied with a marked reduction of growth, and that might be explained by enhancing ethylene production under Cd stress causing a marked inhibitory effect on maize growth.

It has been firmly established that $\mathrm{NO}_{3}{ }^{-}$is taken up via specific channel systems and ATP-dependent plasma membranes-associated carriers (Forde 2000). The suppression of $\mathrm{NO}_{3}{ }^{-}$content and NR activity in leaves and roots of maize plants imposed to $\mathrm{Cd}$ stress might be correlated with $\mathrm{Cd}$-induced disturbance of plasma membranes that might disordered the specific $\mathrm{NO}_{3}{ }^{-}$channels and plasma membrane-associated $\mathrm{NO}_{3}{ }^{-}$carriers. Moreover, the disturbance of cortical cells and vascular system of $\mathrm{Cd}$ stressed roots could lead to suppression of $\mathrm{NO}_{3}$ transportation through xylem elements from roots to leaves. Furthermore, the decline of TAC, the requisite C-skeleton and source of $\mathrm{H}$-donors for nitrogen assimilation might indirectly inhibit NR activity. Besides, the reduction of NR activity in Cd-treated maize plants could be related to the oxidative damage of $\mathrm{NR}$ enzyme and $\mathrm{NO}_{3}{ }^{-}$carrier proteins, by generated ROS and interaction of functional $\mathrm{SH}$ groups of the enzyme with $\mathrm{Cd}$ as well as suppression of NR gene expression (Erdal and Turk 2016).

It is noteworthy that parallel to the suppression of $\mathrm{NO}_{3}{ }^{-}$content and $\mathrm{NR}$ activity in leaves and roots of maize plants imposed to $\mathrm{Cd}$ stress, there was a significant increase of $\mathrm{NH} 4^{+}$content and induction of NADH-GDH. Similarly, several studies have demonstrated a notable increment of NADH-GDH activity under Cd stress (Chaffei et al. 2004; Skopelitis et al. 2006). Singh and Prasad (2017) reported that the suppressed GS and GOGAT activities in Cd-treated tomato seedlings could resulted in a marked disturbance in $\mathrm{NH}_{4}{ }^{+}$assimilation process, and that leads to an increase of $\mathrm{NH}_{4}{ }^{+}$accumulation and a decrease of protein content. Britto and Kronzucker (2002) suggested that NAD(P)HGDH activity (an alternative enzyme for $\mathrm{NH}_{4}{ }^{+}$assimilation) might be enhanced when GS/GOGAT cycle is inhibited to protect the cell damage caused by accumulated $\mathrm{NH}_{4}{ }^{+}$. Thus, it is possible that the increase of NADH-GDH activity was to compensate the decrease of GS activity to sustain $\mathrm{NH}_{4}^{+}$ assimilation resulting in a marked accumulation of $\mathrm{NH}_{4}^{+}$. Application of N-Bio partially shifted off the inhibitory 
consequences of $\mathrm{Cd}$ on both processes as indicated by the significant increase of NR, GS and GDH activities as well as $\mathrm{NO}_{3}{ }^{-}$content in N-Bio-pretreated Cd-stressed plants compared to those of Cd-stressed ones. The increase of $\mathrm{NO}_{3}{ }^{-}$uptake and $\mathrm{NO}_{3}{ }^{-}$transportation and its assimilating enzymes in N-Bio-pretreated maize plants might be attributed to decreased Cd-bioavailability to root system via increase of $\mathrm{Cd}$ adsorption on organic matter (PacwaPłociniczak et al. 2011) and reduction of oxidative damage, hence controlling plasma membrane integrity.

\section{Conclusion}

This study pointed out that N-Bio treatment (Azotobacter spp. and Azospirillum spp.) was able to mitigate Cd toxicity in maize plants causing an increase in growth biomarkers. However, N-Bio pretreatment may have restored the growth of maize plants via increasing of $\mathrm{NO}_{3}{ }^{-}$uptake (content) and modulation of its assimilating enzyme activities (NR, GS, and GDH) as well as suppression of oxidative damage of plasma membranes and improvement of $\mathrm{Cd}$-induced alteration in root anatomical structure. Moreover, inoculation with $\mathrm{N}$-Bio may have enhanced the uptake of $\mathrm{N}$ Bio secreted phytohormones (IAA, $\mathrm{GA}_{3}$ ) which was accompanied with a decrease of ABA content leading to an increase of stomatal opening, $\mathrm{CO}_{2}$ diffusion and finally increasing the photosynthetic efficiency.

\section{Author Contributions}

The authors confirm contribution to the paper as follows: study conception and design: Saber N.E., Abou-Zeid H.M., Ismail G.S.M., following lab experiments: Abdelrahim B.I., Saber N.E., Abou-Zeid H.M., Ismail G.S.M. Data analysis and interpretation: Saber N.E., Abou-Zeid H.M., Ismail G.S.M., Abdelrahim, B.I., draft manuscript preparation: Ismail G.S.M., Abou-Zeid H.M., critical revision of the article and final approval of the version to be published: Saber N.E., Abou-Zeid H.M., Ismail G.S.M.

\section{References}

Agami RA, HA Ghramh, M Hashem (2017). Seed inoculation with Azospirillum lipoferum alleviates the adverse effects of drought stress on wheat plants. J Appl Bot Food Qual 90:165-173

Ahmad M, ZA Zahir, M Khalid, F Nazli, M Arshad (2013). Efficacy of Rhizobium and Pseudomonas strains to improve physiology, ionic balance and quality of mung bean under salt-affected conditions on farmer's fields. Plant Physiol Biochem 63:170-176

Britto D, HJ Kronzucker (2002). $\mathrm{NH}_{4}^{+}$toxicity in higher plants: A critical review. J Plant Physiol 159:567-584

Canovas FM, FR Cantón, F Gallardo, A García-Gutiérrez, A de-Vicente (1991). Accumulation of glutamine synthetase during early development of maritime pine (Pinus pinaster) seedlings. Planta 185:372-378

Chaffei C, K Pageau, A Suzuki, H Gouia, MH Ghorbel (2004). Cadmium toxicity induced changes in nitrogen management in Lycopersicon esculentum leading to a metabolic safeguard through an amino acid storage strategy. Plant Cell Physiol 45:1681-1693
Comstock JP (2002). Hydraulic and chemical signaling in the control of stomatal conductance and transpiration. J Exp Bot 53:195-200

Costa G, E Spitz (1997). Influence of cadmium on soluble carbohydrates, free amino acids, protein content of in vitro cultured Lupinus albus Plant Sci 128:131-140

Divyajyothi LB, B Sujatha (2019). The influence of lead on growth and stomata structure of pigeon pea (Cajanus cajan L.) (Millspaugh) and maize (Zea mays L.). Intl J Rec Sci Res 10:31032-31035

Dubois M, KA Gilles, JK Hamitton, PA Rebers, F Smith (1956). Phenolsulphuric acid colourimetric method. In: Methods in Carbohydrate Chemistry, pp:388-389. Whistler RL, ML Wolfrom (Eds.). Academic Press, New York, USA

Edelstein M, M Ben-Hur (2018). Heavy metals and metalloids: Sources, risks and strategies to reduce their accumulation in horticultural crops. Sci Hortic 234:431-444

Epstein E (1972). Mineral Nutrition of Plants: Principles and Perspectives, pp:115-189. Wiley, New York, USA

Erdal S, H Turk (2016). Cysteine-induced up regulation of nitrogen metabolism-related genes and enzyme activities enhance tolerance of maize seedlings to cadmium stress. Environ Exp Bot 132:92-99

Etesami H (2018). Bacterial mediated alleviation of heavy metal stress and decreased accumulation of metals in plant tissues: Mechanisms and future prospects. Ecotoxicol Environ Saf 147:175-191

Farooq M, A Ullah, M Usman, KHM Siddique (2020) Application of zinc and biochar help to mitigate cadmium stress in bread wheat raised from seeds with high intrinsic zinc. Chemosphere 260; Article 127652

Fatemy F, PKE Trinder, JN Wingfiel, K Evans (1985). Effects of Globoder rostochiensis, water stress and exogenous abscisic acid on stomatal function and water use of Cara and Pentland Dell potato plants. Rev Nématol 83:249-255

Forde BG (2000). Nitrate transporters in plants: Structure, function and regulation. Biochem Biophys Acta 1465:219-235

Fukami J, FJ Ollero, M Megias, M Hurngri (2017). Phytohormones and induction of plant-stress tolerance and defense genes by seed and foliar inoculation with Azospirillum brasilense cells and metabolites promote maize growth. AMB Express 7; Article 153

Gothandapani S, S Sekar, CP Padaria (2017). Azotobacter chroococcum: Utilization and potential use for agricultural crop production: An overview. Intl J Adv Res Biol Sci 4:35-42

Gouda S, RG Kerryb, G Dasc, S Paramithiotisd, H Shine, JK Patrac (2018), Revitalization of plant growth promoting rhizobacteria for sustainable development in agriculture. Microbiol Res 206:131-140

Gowayed SMH, OA Almaghrabi (2013). Effect of copper and cadmium on germination and anatomical structure of leaf and root seedling in maize (Zea mays L.) Aus J Basic Appl Sci 71:548-555

Groat RG, CP Vance (1981). Root nodule enzymes of ammonia assimilation in alfalfa (Medicago sativa L.): Developmental patterns and response to applied nitrogen. Plant Physiol 67:1198-1203

Haneef I, S Faizan, R Perveen, S Kausar (2013). Role of arbuscular mycorrhizal fungi on growth and photosynthetic pigments in Coriandrum sativum L. grown under cadmium stress. J Agric Sci 9:245-250

Hatree EF (1972). A modification of the Lowry method that gives a linear photometric response. Anal Biochem 48:422-427

Hussain B, MN Ashraf, S-U Rahman, A Abbas, J Lia, M Farooq (2021) Cadmium stress in paddy fields: Effects of soil conditions and remediation strategies. Sci Tot Environ 754; Article 142188

Johnson C, A Ulrich (1950) Determination of nitrate in plant material. Anal Chem 22:1526-1529

Kamran MA, JH Syed, SA Eqani, MF Munis, HJ Chaudhary (2015). Effect of plant growth-promoting rhizobacteria inoculation on cadmium (Cd) uptake by Eruca sativa. Environ Sci Pollut Res 22:9275-9283

Kang BG, WT Kim, HS Yun, SC Chang (2010). Use of plant growthpromoting rhizobacteria to control stress responses of plant roots. Plant Biotechnol Rep 4:179-183

Kettner J, K Dorffling (1995) Biosynthesis and metabolism of abscisic acid in tomato leaves infected with Botrytis cinerea. Planta 196:627-634 
Khanna K, SK Kohli, P Ohri, R Bhardwaj, A Al-Huqail, MH Siddiqui, GS Alosaimi, P Ahmed (2019). Microbial fortification improved photosynthetic efficiency and secondary metabolism in Lycopersicon esculentum plants under Cd stress. Biomolcuoles 9; Article 581

Kooten OV, JF Snel (1990). The use of chlorophyll fluorescence nomenclature in plant stress physiology. Photosynth Res 25:147-150

Kovacik J, M Backor (2017). Phenylalanine ammonia-lyase and phenolic compounds in chamomile tolerance to cadmium and copper excess. Water Air Soil Pollut 185:185-193

Li B, C Quan-Wang, H Liu, HX Li, J Yang, W Song, L Chen, M Zeng (2014). Effects of $\mathrm{Cd}^{2+}$ ions on root anatomical structure of four rice genotypes. J Environ Biol 35:751-757

Liu X, S Zhang, XQ Shan, P Christie (2007). Combined toxicity of cadmium and arsenate to wheat seedlings and plant uptake and antioxidative enzyme responses to cadmium and arsenate cocontamination. Ecotoxicol Environ Saf 68:305-313

Mondal NK, C Das, S Roy, JK Datta, A Banerjee (2013). Effect of varying cadmium stress on chickpea (Cicer arietinum 1) seedlings: An ultrastructural study. Ann Environ Sci 7:59-70

Moran R (1982). Formulae for determination of chlorophyllous pigments extracted with N, N-dimethylformamide. Plant Physiol 69:1376-1381

Murata T, T Akazawa, F Shikiko (1968). Enzymic mechanism of starch breakdown in germinating rice seeds I. An analytical study. Plant Physiol 43:1899-1905

Naveed M, MB Hussain, ZA Zahir, B Mitter, A Sessitsch (2014). Drought stress amelioration in wheat through inoculation with Burkholderia phytofirmans strain PsJN. Plant Growth Regul 73:121-131

Nikolić N, L Zoric, I Cvetković, S Pajevic, M Borisev, S Orlovic, A Pilipović (2017). Assessment of cadmium tolerance and phytoextraction ability in young Populus deltoides L. and Populus euramericana plants through morpho-anatomical and physiological responses to growth in cadmium enriched soil. I-For Biogeosci For 10:635-644

O'Neal D, KD Joy (1973). Glutamine synthetase of pea leaves. I. Purification, stabilisation and $\mathrm{pH}$ optima. Arch Biochem Biophys 159:113-122

Pacwa-Płociniczak M, GA Płaza, Z Piotrowska-Seget, SS Cameotra (2011). Environmental applications of biosurfactants: Recent advances. Intl $J$ Mol Sci 12:633-654

Priyadarshini B, B Sujatha (2011). Cadmium-induced plant stress investigated by scanning electron microscopy in Cajanus cajan. $J$ Pharm Res 4:938-941

Rashid MI, LH Mujawara, T Shahzade, T Almeelbia, IMI Ismail, M Ovesaa (2016) Bacteria and fungi can contribute to nutrients bioavailability and aggregate formation in degraded soils. Microbiol Res 183:26-41

Reddy S, AK Singh, H Masih, JC Benjamin, SK Ojha, PW Ramteke, A Singla (2018). Effect of Azotobacter spp. and Azospirillum spp. on vegetative growth of Tomato Lycopersicon esculentum. $J$ Pharmacogn Phytochem 74:2130-2137

Rezvi A, MS Khan (2018). Heavy metal induced oxidative damage and root morphology alterations of maize (Zea mays L.) plants and stress mitigation by metal tolerant nitrogen fixing Azotobacter chroococcum. Ecotoxicol Environ Saf 157:9-20

Roychowdhury R, TF Qaiser, P Mukherjee, M Roy (2017). Isolation and characterization of a Pseudomonas aeruginosa Strain PGP for plant growth promotion. Proc Natl Acad Sci Ind Sect B Biol Sci 89:353-360

Saber NE, WH El-Aggan, SY Barakat, EM Dabash (1989). Nitrate uptake and nitrate reductase in the water-fern Azolla caroliniana. Commun Sci Res 26:111-124
Shah K, AU Mankad, MN Reddy (2017). Cadmium accumulation and its effects on growth and biochemical parameters in Tagetes erecta L. $J$ Pharmacogn Phytochem 6:111-115

Singh S, SM Prasad (2017). Effects of 28-homobrassinoloid on key physiological attributes of Solanum lycopersicum seedlings under cadmium stress: Photosynthesis and nitrogen metabolism. Plant Growth Regul 2:161-173

Singh S, SM Prasad (2014). Growth, photosynthesis and oxidative responses of Solanum melongena L. seedlings to cadmium stress: Mechanism of toxicity amelioration by kinetin. Sci Hortic 176:1-10

Sinha RK, D Valani, K Chauhan, S Agarwal (2014). Embarking on a second green revolution for sustainable agriculture by vermiculture biotechnology using earthworms: Reviving the dreams of Sir Charles Darwin. Intl J Agric Health Saf 1:50-64

Skopelitis DS, NV Paranychianakis, KA Paschalidis (2006). Abiotic stress generates ROS that signal expression of anionic glutamate dehydrogenases to form glutamate for proline synthesis in tobacco and grapevine. Plant Cell 18:2767-2781

Sokal RR, FJ Rohlf (1995). Biometry: The Principles and Practice of Statistics in Biological Research; pp:271-356. Freeman WH (Ed.). New York, USA

Sokhangoy SH, KH Ansari, DA Eradatm (2012). Effect of biofertilizers on performance of dill Anethum graveolens. Ind J Plant Physiol 2:547-552

Solorzano L (1969). Determination of ammonia in natural waters by the phenylhypochlorite method. Limnol Oceanogr 14:799-801

Soudeh F, F Zarinkamar (2012). Morphological and anatomical responses of Matricaria Chamomilla plants to cadmium and calcium. Adv Environ Biol 65:1603-1609

Spurr AR (1969). A low-viscosity epoxy resin embedding medium for electron microscopy. J Ultrastruct Res 26:31-43

Tejada M, B Rodríguez-Morgado, I Gómez, L Franco-Andreu, C Benítez, J Parrado (2016). Use of biofertilizers obtained from sewage sludges on maize yield. Eur J Agron 78:13-19

Turano FJ, R Dashner, A Upadhaya, CR Caldwell (1996). Purification of mitochondrial glutamate dehydrogenase from dark-grown soybean seedlings. Plant Physiol 12:1357-1364

Vejan P, R Abdullah, T Khadiran, S Ismail, AN Boyce (2016). Role of plant growth promoting rhizobacteria in agricultural sustainability-A review. Molecules 21:573-589

Velikova V, F Loreto (2005). On the relationship between isoprene emission and thermotolerance in Phragmites australis leaves exposed to high temperatures and during the recovery from a heat stress. Plant Cell Environ 28:318-327

Venable JH, R Coggeshall (1965). A simplified lead citrate stain for use in electron microscopy. J Cell Biol 25:407-408

Wang F, B Zeng, Z Sun, C Zhu (2009). Relationship between proline and $\mathrm{Hg}^{2+}$ - induced oxidative stress in a tolerant rice mutant. Arch Environ Contam Toxicol 56:723-731

Williams AP (1986). General problems associated with the analysis of amino acids by automated ion-exchange chromatography. $J$ Chromatogr 373:175-190

Xu J, J Sun, L Du, X Liu (2012). Comparative transcriptome analysis of cadmium responses in Solanum nigrum and Solanum torvum. New Phytol 196:110-124

Zemanová V, M Pavlík, D Pavlíková (2017). Cadmium toxicity induced contrasting patterns of concentrations of free sarcosine, specific amino acids and selected microelements in two Noccaea species. PLoS One 125; Article e0177963 